\title{
Marketing Analysis of Locally Produced Rice in Abakaliki Local Government Area of Ebonyi State Nigeria
}

\author{
Anthony Chukwuma Nwali (Ph.D) \\ Anyalor Maureen (B.Sc) \\ Department of Accountancy/Business Administration/Banking and Finance, \\ Alex Ekwueme Federal University Ndufu Alike Ikwo, Ebonyi State, Nigeria
}

Doi: $10.2478 / m j s s-2019-0004$

\begin{abstract}
The study investigated the challenges of marketing Abakaliki rice with interest in establishing the profitability and socio-economic characteristics of the marketer of the product. Mixed-method research approach consisting of the application of questionnaires and interview was used. It was conducted in three major markets located at Onu Ebonyi, Abakpa and Kpirikpiri in Ebonyi state, Nigeria. The population of the study was 120 marketers randomly selected using simple random sampling technique and proportional to the size of the market. Data was analysed using descriptive statistics. The results shows that women dominate the trade as $62 \%$ of Abakaliki rice marketers are women. Challenges of institutional, transportation facilities capital and credit facility constrained the growth of the business. Cost benefit analysis also shows that marketing of Abakaliki rice is profitable as N192, 740 only was the net profit at the end of the trading period. The study concludes by recommending formation of cooperative societies to enhance accessibility of start-up capital while governments at various levels should develop marketing policies that increase the marketing network of Abakaliki rice.
\end{abstract}

Keywords: Market, Marketing analysis; local rice; Abakaliki rice markets

\section{Introduction}

\subsection{Background of the study}

Traditionally, agriculture is assumed to play passive and supportive roles in economic development. Provision of sufficient low-priced food and manpower to the expanding industrial economy, which was thought to be the dynamic "leading sector" in any overall strategy of economic development was the primary purpose (Todaro and Smith, 2011). Emphasis are placed on rapid industrialisation with the agricultural sector fuelling the industrial expansion by way of cheap food, surplus labour, inputs for industry such as textiles, food processing, foreign exchange, rising rural incomes and factor market (labour and capital) contributions.

Between 1980 and 2004 as estimated by the World Bank and cited by (Todaro and Smith 2011) note that developing countries record faster growth rate in the value of agricultural output of $2.6 \%$ per year as against $0.9 \%$ per year of the developed economies. This growth is all inclusive and could be a reaction to the remarks of one time Secretary General of the United Nations and first Chairman of the Alliance for a Green Revolution in Africa, Kofi Annan. The Secretary observes that "Africa is the only region where overall food security and livelihood are deteriorating and efforts shall be intensified to reverse this trend by working to make available an environment that is sustainable, uniquely African Green Revolution where our poorest finally prosper and all Africans will benefit". 
Agriculture the world over not just Africa or Nigeria in particular remains the central focus of most administrations and to this end governments at different levels have been taking deliberate actions to encourage greater participation in order to boost production. Nigeria is the largest producer of rice in the West African Sub-Region, (Chima 2002). Nigeria.aress.ppt. By 2002, the country accounted for $57 \%$ of the total rice produced in West Africa despite the fact that only $35 \%$ of the available land for rice production estimated at between $4.6 \mathrm{~m}$ and $4.9 \mathrm{~m}$ hectare was cropped.

Long before the creation of Ebonyi state in 1996, Abakaliki was known as having the highest concentration of rice mills in West Africa, http://www.mynewswatchtimesng.com. About 300 mills at various locations in the state where processing and marketing to both whole-sellers and retailers take place are privately owned. Ikwo, Abakaliki, Izzi, Ebonyi, Afikpo South and Ivo are notable places where massive rice farming takes place. The productive activities of these farming locations have increased rice production and with this, a complete marketing system for the product began to evolve to absorb the surplus quantity produced. Ebonyi state remains the hub of rice production in Nigeria and this is very strategic to the realisation of the Federal Government's agenda of attaining rice sufficiency in a short while according to Orogwu (2014), one time Permanent Secretary, Ministry of Agriculture and Natural Development.

This paper therefore evaluates the marketing analysis of locally produced rice in Abakaliki Local Government Area of Ebonyi State.

\subsection{Statement of problem}

In spite of the role rice plays in human life and its effect on the economic development of Nigeria, researchers have tended to ignore scholarly investigations on the constraints and challenges militating against marketing locally produced rice in Abakaliki. It is only when such studies are conducted that solutions can be provided to both rice farmers and traders on the appropriate and ethical ways of marketing rice to their esteemed customers profitably. It is on this disconnection that this study intends to address.

\subsection{Objectives of the study}

The broad objective of the study is to evaluate marketing system of locally produced rice in Abakaliki Local Government of Ebonyi state. The specific objectives are:

1. To examine the socio-economic characteristics of the respondents within the scope of the study.

2. To establish the basic constraints of marketing locally produced rice in Abakaliki Local Government Area of Ebonyi State.

3. To estimate the profitability of marketing locally produced rice in Abakaliki Local Government Area of Ebonyi State.

\subsection{Research questions}

On the basis of the above research objectives, the following research questions are hereby formulated:

1. How does the composition of the socio-economic characteristics of the respondents affect marketing of Abakaliki rice?

2. What are the constraints militating against the appreciable marketing of Abakaliki rice?

3. What are those factors that can be introduced to estimate the profitability of marketing of Abakaliki rice?

\subsection{Significance of the Research}

This study will provide useful information on the most appropriate ways of marketing Abakaliki rice. It will be of specific value to the coordinators of various rice mills in the state, Rice Producers and Marketers Associations, rice consumers and intending researchers on rice production and marketing in Abakaliki. 


\subsection{Scope of the study}

The study was conducted in Abakaliki Local Government Area of Ebonyi state. Incidentally, Abakaliki is the capital of Ebonyi state and it is located 64 kilometres Southeast of Enugu state. The name which means Aba Nkaleke is derived from a community in Izzi land -Nkaleke. Abakaliki is the centre of agricultural trade like yams, cassava, rice, kola nuts, palm oil and palm kernels, (Cohen, (1998). Cohen (1998) in Heiberg (2010) notes that the state is equally famous in the production of local lead, zinc, salt, limestone and quarry. The increase in agricultural related businesses is traceable to tax holiday and huge incentives of state government to major private investors. The state government also promotes both poultry and egg production (Cohen, Saul B. 1998).

In the state, there exist a number of markets where rice is a major commodity of merchandise and this further justifies why this study has decided to analyse the marketing system of Abakaliki rice.

\section{Theoretical Framework}

\subsection{Market Analysis}

The theory of market analysis establishes the attractiveness of a market now and in the future (Aaker, 2010). Determining opportunities and threats as they concern strength and weaknesses are the major objectives of evaluating future attractiveness of organisations as the investment options and choices are guided by the findings of such evaluations. Investment strategies are often adjusted to align with the market analysis findings and inventory levels, increase/decrease of workforce, facility expansion, procurement of capital equipment and reward system are vulnerable areas that may be affected by such adjustment. The author further explains market analysis in four dimensional approaches environmental analysis, competitive analysis, target audience analysis and SWOT analysis. Current trends as they affect profitability are the main focus of market analysis and can equally be seen as part of industry analysis through the application of global environmental analysis.

In summary, Aaker (2010) argued that the theoretical foundation of market analysis is the determination of the following factors: market size, market growth rate, market profitability, industry cost structure, distribution channel and market trends and that differentiated market analysis is based on market segmentation. As competition increases, consumption gets saturated and to obtain full knowledge and information about the market so that relevant market is defined for individual products and services, market research is involved.

\subsubsection{Conceptual framework}

\subsubsection{Market}

A market "is a set of actual and potential buyers of a product" (Kotler, 1980). This is an advanced strategy of obtaining desired needs because of the introduction of a merchant or central place that exchange process takes place. In a given volume of exchange, the presence of merchant/market reduces the number of transactions required (Alderson 1957 in Kotler 1980). A market can spring up around a product, service or anything of value to the participants. For instance, the emergence of money market is to respond to the needs of applicants desiring to borrow, save, lend and/or secure their money.

\subsubsection{Marketing}

Marketing is a matching process between a company's capabilities and the wants of customers, (McDonald, 1999). It is the creative management function which promotes trade and employment by establishing consumer needs and initiating research and development to meet them, (Appleby, 1981). In other words, it is the process of identification of customers' needs and matching such needs satisfactorily and profitably. It also involves thorough explanation of the unique features and characteristics of the product which are not found in other similar products in order to obtain 
customer patronage and loyalty. Wang and Luh, (1991) observe that, just like in other products, improved handling of rice can greatly enhance productivity, reduce grain losses arising from processing technologies and improve its marketability.

Kotler (1980) explains marketing as a "human activity directed at satisfying needs and wants through exchange process". The complexity and ever abundant human needs are basic parts of life and if such needs are unsatisfied, it creates unhappiness and tension. A need is the emergency of felt deprivation. Wants on the other hand is dictated by our need and shaped by our culture and individuality. Porter (1979) argues that wants are described in terms of culturally defined objects that have the ability of satisfying the identified need. Exchange in the words of Porter (1980) involves trading-off a desired object by offering something in return. Exchange is a unique human activity that promotes specialisation of skills.

\subsubsection{Market Analysis}

Market analysis is the assessment of the growth and profit opportunities likely to be open to it in the candidate market (Michael (2001). Furthermore, it is a part of business plan that gives information about the commercial market in which the business operates, purchasing habits of customers in the market and possible information about competitors. Market analysis is a process of evaluating market size, growth rate of the market, profitability, cost structure of the industry, channels of distribution, market trends as well as key success and failure factors.

Market size entails assessing and determining the current sales and applying such to estimate future sales if the product patronage increases. Market analyses based on the growth rate of the market emphasises the need to look at growth drivers as well as the sales growth of complementary products.

Profitability determination involves is the application of the average profit potential arising from the different profitability levels of different forms in a market. This provides a guide on the profitability of making money. Market profitability factors include buyer power, supplier power, barriers to entry, threat to substitute and rivalry among firms.

Cost structure is useful in establishing key success factors and in this regard, when value is added on a product, it is important to evaluate the associated costs. Market trends help to find out changes in the market so that opportunities and threats can be determined. For marketing objectives to be achieved, it is necessary to know the effect certain factors have on marketing the products. Such factors include progress in technology, access to channels of distribution and other factors that can promote product growth and acceptability.

Rice marketing is the performance of all business activities from paddy, the milled and initial production to the hands of final consumers at the right price, time and profit margin that can sustain both the farmers and marketers (Iheme, 1996). This seemingly simple but complicated exercise is complemented by the activities of marketing channels that direct the path of a product from its raw state to the producers and eventually final consumers. Channels of distribution entail assessing existing channels, trends and power .It is made up of institutions and individuals acting as middlemen and link between the producers and consumers. Ogundele, (2013) notes that the middlemen are the private individuals carrying out various marketing functions of buying and selling from the producers to the consumers respectively.

In summary, the goal of market analysis is to determine the attractiveness of a market and to understand its evolving opportunities and threats as they relate to the strengths and weaknesses of the firm (http://www.netmba.com/marketing/market/analysis.

\subsubsection{Rice}

The world over, rice remains the most consumed cereal grain grown and the third largest produced food crop (http://www.cookingganyfood.com). The International year of Rice Report of 2004 noted that Thailand is the biggest exporter of rice with an approximate record figure of $7.6 \mathrm{~m}$ tons yearly; Viet Nam exports $3.7 \mathrm{~m}$ tons annually while the United States of America exports $2.6 \mathrm{~m}$ tons annually.

Rice contains b-sistosterol, a natural substance that lowers blood cholesterol levels (http://www.Rice Milk.com). There are over 140,000 varieties of rice with the long, medium and 
short grains as the commonest. There is also brown rice that only the husk is removed and the white ones that much of its nutritional values are stripped during the milling stage thereby making the brown species higher in nutrition.

Nutritionally, rice contains complex carbohydrates that give energy to the body and fuel for the brain for proper functioning. Rice provides vitamins such as riboflavin, thiamine and niacin (http://www.RiceTrade.com). It also contains iron, vitamin ' $D$ ' and calcium as well as eight amino acids which make it a good source of protein.

\subsubsection{Challenges of Marketing Abakaliki Rice}

One of the major reasons for poor performance of local rice production and marketing is the neglect of the sector in the development priorities of the governments. Marketing can only take place when the products to be marketed are available. Mbam (2014) and one time interim Chairman of the Rice Mill Owners Industrial Enterprise notes that some of the challenges are lack of irrigation to guarantee all year production of rice, constraints of institutional and financing to enhance production and stocking, shortage of marketing opportunities, problems of transportation facilities occasioned by bad roads, lack of capital and credit facility and absence of price control agencies to check price fluctuations. Therefore, getting the role of government right in agriculture generally and rice production in particular has remained a serious challenge to the development of rice production and marketing of Abakaliki rice in Ebonyi state.

\subsubsection{Empirical Framework}

In a study conducted by Duc Hai (2003) on the organisation of liberalized rice market in Vietnam, findings indicated that competitiveness in major rice markets as there was no restrictions on entry, absence of concentration of market share in private hands, products were not differentiated and accessibility of information. Similarly, Harahap (2004) noted that rice distribution was a strong determinant in rice supply in a rice chain study in farmers' community in Indonesia. Wolelaw (2005) in a study to identify main determinants of rice supply using Cobb Douglas model to establish the limiting factors noted current price, one year lagged price, actual consumption, total rice production, distant to the market significantly affected rice supply. Tenagne (2005) surveyed the challenges of rice production, utilisation and marketing at Fogera, Dera and Libokemke districts noted production and market variables as major constraints.

\section{Methodology}

\subsection{Research Design}

Survey research design was adopted in this study and it involved the administration of questionnaires to obtain responses from the respondents. Observable, measurable and verifiable variables as contained in the objective of the study are assigned values. Specifically, the study applied questionnaires technique as tool for data collection. Qualitative technique in the form of interview was selectively used in order to establish better understanding of the intents of the respondents.

\subsection{Participants/population}

The participants were solely drawn from Abakaliki rice dealers in Onu Ebonyi Rice Mill, Abakpa and Kpirikpiri Markets. A total of 105 participants were sampled and they consist of 40 males and 65 females. Their ages range from 25 years to 46 years and above. Recognising their marital status, 25 of the participants were single, 65 were married, 5 divorcees and 10 were widows. On educational background, 10 participants had post secondary education while 59 participants had secondary education and 36 participants obtained only primary education. Only 29 of the participants had been in the business for between $1-15$ years, while 43,21 and 12 participants had $16-25$ years, $26-35$ years and above 36 years experience respectively. 


\subsection{Sampling procedure}

Abakaliki rice is sold in almost all the major markets in Abakaliki Local Government Area and even beyond. This underscores the acceptability of Abakaliki rice and the potential it has in addressing ever increasing rice demands in Nigeria thereby replacing importation from Thailand, America and other rice producing countries. For the purpose of this study therefore, three major markets located at Onu Ebonyi, Abakpa and Kpirikpiri in Abakaliki are selected purposively for sampling. One hundred and twenty (120) marketers were randomly selected using simple random sampling technique and proportional to the size of the market. Data was collected through primary sources and it was conducted with the aid of structured questionnaire administered to rice marketers in the three selected major markets. A total of 120 questionnaires were administered to the three major markets thus: Onu Ebonyi Rice Mill (55), Abakpa Market (35) and Kpirikpiri Market (30). Only 105questionnaires were properly completed and recovered as follows: Onu Ebonyi Rice Mill (50), Abakpa Market (30) and Kpirikpiri (25). This is $87.5 \%$ response rate and $12.5 \%$ non-response rate.

\subsection{Techniques for Data Analysis}

The analytical technique for this study is mainly descriptive such as frequency count and percentage to determine the socio-economic characteristics, profitability, basic constraints/challenges and possible suggestions on marketing Abakaliki rice. Return on investment (ROI), Profit and Gross Margin formed part of the data analysed using descriptive statistics. The profitability of marketing Abakaliki rice is calculated using gross margin. The following equation was applied to determine the profit: TI - TVC = GM

Where $\mathrm{TI}=$ Total Income, $\mathrm{TVC}=$ Total Variable Costs and GM = Gross Margin .

Objective 1: Determination of bio-data and the Socio-economic characteristics of Rice Marketers in Abakaliki Local Government Area of Ebonyi state

Table 1: Characteristics of rice markers in Abakaliki Local Government Area of Ebonyi state

\begin{tabular}{|c|c|c|c|c|}
\hline$S / n$ & Questions & Response & Frequency & Percentage \\
\hline & Gender & $\begin{array}{l}\text { Male } \\
\text { Female }\end{array}$ & $\begin{array}{l}40 \\
65\end{array}$ & $\begin{array}{l}38.10 \\
61.90\end{array}$ \\
\hline & Total & & 105 & 100 \\
\hline & Age & $\begin{array}{l}\text { Below } 25 \\
26-45 \\
46 \text { and above }\end{array}$ & $\begin{array}{l}10 \\
61 \\
34\end{array}$ & $\begin{array}{l}09.52 \\
58.10 \\
32.38\end{array}$ \\
\hline & Total & & 105 & 100 \\
\hline \multirow[t]{2}{*}{3} & Marital Status & $\begin{array}{l}\text { Single } \\
\text { Married } \\
\text { Divorced } \\
\text { Widowed }\end{array}$ & $\begin{array}{l}25 \\
65 \\
05 \\
10\end{array}$ & $\begin{array}{l}23.81 \\
61.91 \\
04.76 \\
09.52\end{array}$ \\
\hline & Total & & 105 & 100 \\
\hline \multirow[t]{2}{*}{4} & Educational Level & $\begin{array}{l}\text { Tertiary Institution } \\
\text { Secondary School } \\
\text { Primary School }\end{array}$ & $\begin{array}{l}10 \\
59 \\
36\end{array}$ & $\begin{array}{l}09.52 \\
56.19 \\
34.29 \\
\end{array}$ \\
\hline & Total & & 105 & 100 \\
\hline \multirow[t]{2}{*}{5} & $\begin{array}{l}\text { Experience in Marketing } \\
\text { Abakaliki Rice }\end{array}$ & $\begin{array}{l}01-15 \text { years } \\
16-25 \text { years } \\
26-35 \text { years } \\
36 \text { years above }\end{array}$ & $\begin{array}{l}29 \\
43 \\
21 \\
12\end{array}$ & $\begin{array}{l}27.62 \\
40.95 \\
20.00 \\
11.43\end{array}$ \\
\hline & Total & & 105 & 100 \\
\hline \multirow[t]{2}{*}{6} & Sources of Capital & $\begin{array}{l}\text { Personal Savings } \\
\text { Loan from Govt. } \\
\text { Support from friends and relations } \\
\text { Loan from Cooperative Society }\end{array}$ & $\begin{array}{l}68 \\
\text { Nil } \\
14 \\
23\end{array}$ & $\begin{array}{c}64.76 \\
\text { Nil } \\
13.33 \\
21.91\end{array}$ \\
\hline & Total & & 105 & 100 \\
\hline
\end{tabular}

Source: Field Survey, 2015 
Objective 2: Establishment of basic constraints of marketing locally produced rice in Abakaliki Local Government Area of Ebonyi state

Table 2: Identification of challenges/constraints of Marketing Abakaliki Rice

\begin{tabular}{|c|l|l|c|c|}
\hline S/N & Question & Response & Frequency & Percentage \\
\hline & & Bad Roads & 20 & 19.05 \\
& & Government Policies & 32 & 30.48 \\
& & Absence of Irrigation & 21 & 20.00 \\
1 & \multirow{3}{*}{ Challenges/Constraints } & Inadequate Capital & 15 & 14.29 \\
& & Storage Facilities & 10 & 09.52 \\
& & Price Fluctuation & 05 & 04.76 \\
& & Damages & 02 & 01.90 \\
\hline & Total & & 105 & 100 \\
\hline
\end{tabular}

Source: Field Survey, 2015

Objective 3: Profit determination of marketing locally produced rice in Abakaliki Local Government Area of Ebonyi state

Table 3: Financial Implications and determination of profitability of Marketing Abakaliki Rice

\begin{tabular}{|c|c|c|c|}
\hline Items & & & Amount (N) \\
\hline Total Income & \multicolumn{3}{|r|}{$900,000.00$} \\
\hline Variable Costs & \multirow{2}{*}{\multicolumn{3}{|c|}{$\mathrm{N} 631,400.00$}} \\
\hline Cost of rice (purchase) & & & \\
\hline Transportation & \multicolumn{3}{|l|}{$11,560.00$} \\
\hline Labour of de-stoning & \multicolumn{3}{|c|}{$1,000.00$} \\
\hline Cost of bags & \multicolumn{3}{|c|}{$3,600.00$} \\
\hline Various market union levies & \multicolumn{3}{|c|}{$3,200.00$} \\
\hline Local Govemment rates/taxes & \multicolumn{3}{|c|}{$7,000.00$} \\
\hline Rat killer & \multicolumn{3}{|l|}{$1,000.00$} \\
\hline Other costs & \multicolumn{3}{|l|}{$3,000.00$} \\
\hline Total variable cost (TVC) & \multicolumn{3}{|c|}{$661,760.00$} \\
\hline Fixed Costs & & & \\
\hline Bushel (small and big) & \multicolumn{3}{|l|}{$8,000.00$} \\
\hline Tin & \multicolumn{3}{|l|}{500.00} \\
\hline Cutter & \multicolumn{3}{|l|}{200.00} \\
\hline Shop rent & \multicolumn{3}{|l|}{$36,000.00$} \\
\hline Other smaller measures & \multicolumn{3}{|l|}{800.00} \\
\hline Total fixed cost (TFC) & \multicolumn{3}{|c|}{$45,500.00$} \\
\hline Gross Margin (TI - TVC) & \multicolumn{3}{|c|}{$238,240.00$} \\
\hline Net Profit (GM -TFC) & \multicolumn{3}{|l|}{$192,740.00$} \\
\hline
\end{tabular}

Source: Field Survey, 2015

\section{Results and Discussion of Findings}

\subsection{Socio-Economic Characteristics of Abakaliki Rice Marketers}

Marketing analysis of locally produced rice in Abakaliki local government area is as shown on table 1. The variables studied are age, marital status, educational level, marketing experience, and sources of capital. Findings indicate that $62 \%$ of rice marketers in Abakaliki are female while $38 \%$ are male. This indicates that those dominating the trade are women. The table also shows that $58 \%$ of those in the trade are between the ages of 26 to 45 years, $34 \%$ are those above 46 years of age while $9 \%$ of those in the business are less than 25 years old. It implies that the business is dominated by the middle aged, the active productive age of any economy, perhaps due to the 
physical energy requirement of the business.

$61 \%, 24 \%, 10 \%$ and $5 \%$ of the respondents that market Abakaliki rice are married, single, widowed and divorced respectively. Secondly, school leavers are more in the trade as $56 \%$ of the respondents attended secondary school while $34 \%$ and $10 \%$ attended primary school and tertiary institution respectively. Most of the marketers have long standing experience as $41 \%$ of the respondents have 16 to 25 years of experience, $28 \%$ have 01 to 15 years of experience, $20 \%$ have 26 to 35 years of experience and $11 \%$ have over 36 years of experience. Capital is mainly sourced from personal savings as majority of the respondents, 68 , agreed that they obtained their start-up capital from personal savings. Nobody among the respondents sourced initial capital from the government while 23 and 14 respondents obtained their initial capital from cooperative societies and support from relatives/friends respectively.

\subsection{Factors militating against marketing of Abakaliki Rice}

Table 2 shows forces challenging marketing of Abakaliki rice. 32 out of the 105 respondents agreed that government policies have been affecting their operations while 21 and 20 respondents opined that absence of irrigation, road accessibility especially during the flooding periods and poor road network/connectivity have continued to threaten and weaken the marketing potentials of rice marketers. There were also reactions on inadequate capital, storage facilities, price fluctuations and damages as 15, 10, 5 and 2 respondents agreed that those factors affected their business operations tremendously. All these constraints are aggregated to poor government policies. This agrees with the submission of Sczepanik in Todaro and Stephem, (2011) that neglect of the agricultural sector accounted for major reasons of poor performance of rice production and marketing.

\subsection{Determination of Profitability of Marketing Abakaliki Rice}

The financial implications of marketing Abakaliki rice as contained on table 3 shows that the estimated total variable cost was N66, 760.00 while the average total income as obtained from the marketers amounted to N900, 000.00 only, with a gross margin of N238, 240.00 and the net profit was N192, 740.00 only. The cost benefit analysis indicates that the business of marketing Abakaliki rice is lucrative and profitable. Perhaps, this may be associated to unfavourable government policy on importation of rice that consequently increased the demands and consumption of local rice. Some of the marketers interviewed argued that the unprecedented and sudden increase in the price of foreign smuggled rice due to the ban promoted tremendously the business of marketing Abakaliki rice in the state and beyond.

\section{Conclusion}

The study shows that $62 \%$ of Abakaliki rice marketers are women while $58 \%$ are of middle age. $62 \%$ are married, $56 \%$ have secondary school education, $41 \%$ have 16 to 35 years of experience in marketing Abakaliki rice and $65 \%$ obtained their initial start-up capital from personal savings. The greatest challenges facing marketing of Abakaliki rice are government policies, bad roads and inadequate capital to expand the business. With a net profit of N192, 740.00, it implies that marketing of Abakaliki rice is indeed profitable, reported challenges not with- standing.

\section{Recommendations}

Based on the findings of this study, the following recommendations are made:

1. Since the trade is dominated by females coupled with the appreciable level of literacy, formation of cooperative societies to boost capital formation is an added advantage.

2. Agricultural policies and programmes should be tailored towards infrastructural provision in the areas of roads construction and irrigation to increase rice production. Roads in Nigeria are not just in deplorable conditions but poorly connected, making distribution from the 
farm to various points cumbersome. Marketing policies and programmes should also create awareness on the nutritional advantage of consuming local rice.

3. Finally, with the lucrative nature of trading in Abakaliki rice and the provision of the earlier recommendations, large-scale industries may begin to emerge rapidly to absorb and engage the teaming youths particularly the females entrepreneurially to challenge what seemed a deliberate placement of lid on this area of youth empowerment.

\section{References}

Aaker. D.A. \& McLouthlin, D.(2010). Strategic Market Management - Global Perspective. West Sussex. John Wiley \& Sons Limited.

Appleby, R.C. (1981): Modern Business Administration, $3^{\text {rd }}$ ed. Pitman Pub. Ltd, Marshfield, Massachusetts

Cohen, S. B., (1998): Abakaliki. The Columbia Gazetteer of the world. 1: New York, Columbia University Press

David A.A (2010): Market Analysis. [Online] Available: http://www.netmba.com/market/analysis.

Delane E.W. (1964): Rice Marketing in Eastern Nigeria. Ph.d thesis, Michgan state Universithy.

Harahap, H. (2003). Rice Chain Analysis in North Sumatra, Indonesia; Institute. (eds). Rice improvement in Eastern, Central and Southern Africa. Proceedings of the International Rice Conference.

Hoiberg, D. H. (2010): Abakaliki. Encyclopedia Britannica, 1: A-ak Bayes, Chicago, IL: Encyclopedia Britannica Inc. [Online] Available: (http://en.wikipedia.org/wrk/Abakaliki)

Iheme, D.A. (1996): The Marketing of Staple Food Crops in Enugu State, Nigeria. A Case Study of Rice, Maize and Beans; Unpublished M.Sc. Dissertation, Faculty of Agriculture, University of Nigeria, Nsukka.

Malcolm M. (1999): Marketing Plans, $4^{\text {th }}$ ed. Butterworth Heinemann, Jordan Hill, Oxford, New Delhi

Marketing Analysis: The U.S. Small Business Administration. [Online] Available: http://www.sba.gov/content/martet - analysis

Mbam, P. (2014): Chairman of Rice Mills Owners Industrial Enterprise: How many millers operate at Abakaliki Rice Milling Cluster Agro Business. [Online] Available: News,http://agronigeria.com/2014:

Michael J.B. (2001): The Marketing Book, $4^{\text {th }}$ ed. Butterworth Heinemann, Jordan Hill, Oxford, New Delhi

Michael Porter: Market Analysis. [Online] Available: http://www.netmba.com/marketing/market/analysis

Ogundele, O.O. (2013): Characterisation of Marketing System for Local Rice in Nigeria. A paper presented at NISER, Ibadan.

Osarenren C.O. and Adams O.O. (2014). Marketing analysis of smoke-dried fish in Etsako East Local Government Area of Edo State, Nigeria. Net Journal of Agricultural Science vo. 2(3) pp $104-106$.

Rehima, M. (2006). Analysis of Red Pepper Marketing: The case of Alaba and Siltie in SNNPRS of Ethiopia. An M.Sc. Thesis Presented to the School of Graduate Studies of Hararnays University.

Tenagne, K. (2005). Rice Processing and Utilization: Proceedings of the National Workshop on the Status of Rice Research and Promotion in Ethiopia. Bahir Dar, Ethiopia, $3^{\text {rd }}$ to $4^{\text {th }}$ June, 2005, Amhara Regional Agricultural Research Institute

Todaro P.T. and Stephem, C.M. (2011): Economic Development. $11^{\text {th }}$ ed. Pearson Educational Ltd, Edinburgh Gate, England

Ufoma, K. (2013): Abakaliki rice, key to Ebonyi agro revolution. [Online] Available: http://www.mynewswatchtimes.ng.com

Wang, C.Y. and Luh, B.S. (1991): Harvest, Drying and Storage of Rough Rice in Rice Production, Vol. 1 edited by Luh B.S. Van Nostrand Reinhhold, New York

Wolelaw, S. (2005). Factors determining supply of rice: A case study in Fogera district of Ethiopia. An M. Sc. Thesis Presented to the School of Graduate Studies of Hararnay University. 